\title{
Penggunaan Abu Vulkanik Sinabung Terhadap Stabilitas Campuran Aspal Beton (Hot Mix)
}

\author{
Oloan SITOHANG ${ }^{1} \cdot$ Silvia SINUHAJI ${ }^{2}$
}

\begin{abstract}
Mount Sinabung located in Karo regency North sumatera has continuously been erupting since 2010, generating vast amount of waste in the form of volcanic ash. This research aims to investigate the feasibility of utilizing this volcanic ash in asphalt mixture. We used volcanic ash to replace the conventional filler material from stone crush. Sinabung volcanic ash has lower specific gravity, therefore could fill more void in the asphalt mixture, which can affect the value of Marshall test criteria. Asphalt mixture in this study uses the procedure of Hot Mix Asphalt with mixing temperature ranging from $135^{\circ} \mathrm{C}-150^{\circ} \mathrm{C}$. The result shows that the use of Sinabung volcanic ash is feasible to replace the conventional stone crush filler material in these conditions: optimum asphalt content is 6.85\%; percentage of volcanic ash-stone ash $50 \%-50 \%$. According to national standards issued by Bina Marga of Ministry of Public works, the following values comply with the required value. Bulk density density $2.416 \mathrm{~kg} / \mathrm{cm}^{3}$, air void $4.724 \%$, Void in Mineral Aggregat 18.667 Void Fillet with Asphalt $74.706 \%$, stability 1000,992 kg, Marshall quotient $3.132 \mathrm{kN} / \mathrm{mm}$, and flow $3.133 \mathrm{~mm}$.
\end{abstract}

Kata kunci: abu vulkanik, syarat spesifikasi Marshall Test

\section{Pendahuluan}

Letusan Gunung Sinabung menghasilkan banyak abu vulkanik dan batu yang berdampak bagi kesehatan dan lingkungan. Karena kandungan silika yang tinggi, dilakukan pengujian untuk menambahkan abu vulkanik tersebut terhadap campuran aspal. Lapisan permukaan (surface course) adalah lapisan yang terdiri atas campuran agregat dan bahan pengikat yang ditempatkan sebagai lapisan paling atas.

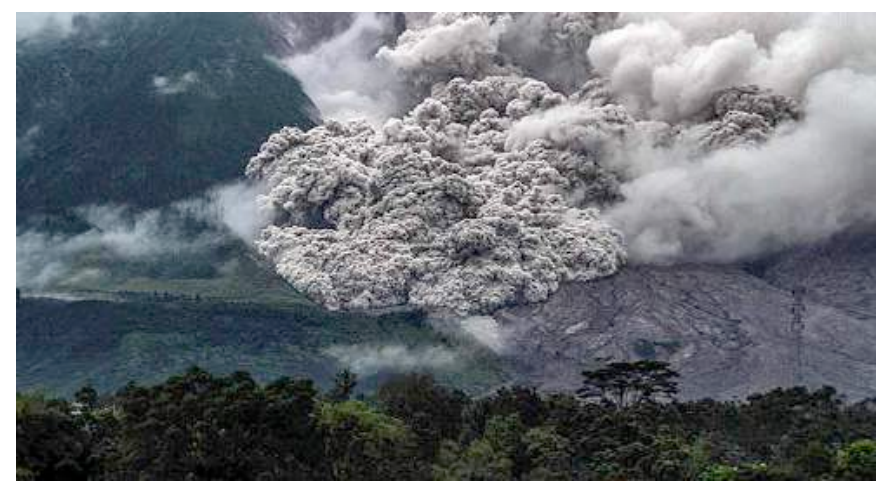

Gambar 1. Gunung Sinabung Sedang Erupsi di Karo, 3 November 2017

Bahan penyusun aspal beton terdiri dari agregat sebagai bahan pokok yaitu agregat kasar, agregat halus, bahan pengisi (filler) dan aspal sebagai bahan pengikat. Jumlah filler yang digunakan dalam campuran biasanya tergantung pada formula campuran, kondisi iklim, sifat

\footnotetext{
${ }^{1}$ Staf Pengajar Teknik Sipil Universitas Katolik Santo Thomas e-mail: obed_sito@yahoo.com

${ }^{2}$ Program Studi Teknik Sipil Universitas Katolik Santo Thomas
} 
kimia dan fisika filler tersebut. Karakteristik yang harus dimiliki oleh filler yaitu tidak reaktif, tidak larut dalam air, tidak higroskopis, berwarna gelap, dan tidak hancur saat proses pencampuran. Dalam hal ini secara kasat mata abu vulkanik memenuhi karakteristik tersebut, sehingga pemanfaatan Abu Vulkanik Sinabung sebagai bahan filler pada campuran aspal beton perlu diteliti. Sedangkan kandungan abu vulkanik tidak jauh beda dengan abu batu ataupun semen, di mana kandungan abu vulkanik adalah Silika ( $\mathrm{Si}$ ) 73,724\%; besi (Fe) 0,0724\%; Aluminium (Al) 7,0488\%; Kalsium (Ca) 0,74\%; Magnesium (Mg) 0,123\%; Kadar air $4,97 \%$.

Penelitian ini bermaksud untuk mengetahui pengaruh pemanfaatan Abu Vulkanik Sinabung dan pasir vulkanik Sinabung dalam campuran aspal beton. Lebih lanjut, tujuan penelitian adalah:

1. Mengetahui pengaruh abu Vulkanik Sinabung dalam campuran aspal beton yang memenuhi syarat dan layak digunakan sebagai lapisan permukaan perkerasan jalan.

2. Mengetahui pengaruh pasir vulkanik terhadap campuran aspal beton.

Penelitian diharapkan dapat memberi manfaat dalam memberikan rekomendasi potensi abu vulkanik Sinabung sebagai bahan pengganti Filler dan agregat halus pada perkerasan aspal beton, serta dalam pengembangan ilmu pengetahuan peneliti-peneliti muda.

\section{Tinjauan Pustaka}

\section{Lapis Permukaan (Surface Course)}

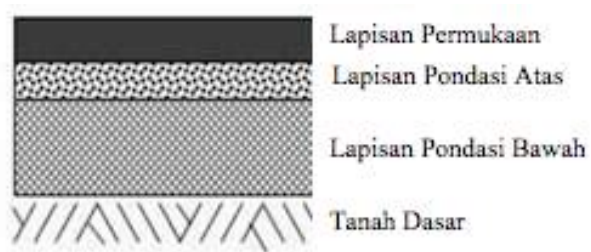

Gambar 2. Lapisan Perkerasan

Lapisan yang terdiri atas campuran mineral agregat dan bahan pengikat (aspal) yang ditempatkan sebagai lapisan paling atas. Fungsi lapisan ini, sebagai:

- Lapisan perkerasan, dengan persyaratan mempunyai stabilitas tinggi selama masa layannya.

- Lapisan kedap air, air hujan tidak meresap ke lapisan di bawahnya dan melemahkan lapisan tersebut.

- Lapis aus (wearing course), lapisan menerima gesekan rem kendaraan sehingga mudah menjadi aus.

- Lapis yang menyebarkan beban ke lapisan bawahnya.

\section{Bahan Penyusun Aspal Beton}

Menurut RSNI M 01-2003, Aspal beton merupakan campuran yang homogen antara agregat (agregat kasar, agregat halus dan bahan pengisi/filler) dan aspal sebagai bahan pengikat yang mempunyai gradasi tertentu, dicampur, dihamparkan dan dipadatkan pada suhu tertentu untuk menerima beban lalu lintas yang tinggi.

\section{Agregat Kasar}

Bina Marga mensyaratkan agregat kasar yang tertahan saringan no. $8(2,36 \mathrm{~mm})$ dan harus bersih, keras, awet dan bebas dari lempung atau bahan yang tidak dikehendaki dan memenuhi ketentuan seperti pada Tabel 1. 
Tabel 1. Ketentuan Agregat Kasar

\begin{tabular}{|l|l|l|}
\hline Pengujian & Standar & Nilai \\
\hline Abrasi dengan mesin Los Angles & SNI 03-2417-1991 & Maks. 40\% \\
\hline Kelekatan agregat terhadap aspal & SNI 03-2439-1991 & Min. 95\% \\
\hline Angularitas (kedalaman dari permukaan $<10 \mathrm{~cm})$ & \multirow{2}{*}{ SNI 03-6877-1991 } & $95 / 90(*)$ \\
\cline { 1 - 1 } Angularitas (kedalaman dari permukaan $\geq 10 \mathrm{~cm})$ & & $80 / 75(*)$ \\
\hline Partikel Pipih dan Lonjong $(* *)$ & ASTM D-4791 & Maks. 10\% \\
\hline Material lolos Saringan No. 200 & SNI 03-4142-1996 & Maks. 1\% \\
\hline
\end{tabular}

(*) 95/90 menunjukkan bahwa 95\% agregat kasar mempunyai muka bidang pecah satu atau lebih dan $90 \%$ agregat kasar mempunyai muka bidang pecah dua atau lebih.

(**) Pengujian dengan perbandingan lengan alat uji terhadap poros 1:5

Sumber : Direktorat Jendral Bina Marga 2009

Agregat Halus (Fine Aggregate/FA)

Agregat halus adalah material yang lolos saringan No.8 $(2,36 \mathrm{~mm})$ dan tertahan saringan No.200 $(0,075 \mathrm{~mm})$ dengan ketentuan seperti pada Tabel 2.

Tabel 2. Ketentuan Agregat Halus

\begin{tabular}{|l|l|l|}
\hline Pengujian & Standar & Nilai \\
\hline Nilai Setara Pasir & SNI 03-4428-1997 & Min. 50\% \\
\hline Material Lolos Saringan No.200 & SNI 03-4142-1996 & Maks. 8\% \\
\hline $\begin{array}{l}\text { Angularitas (kedalaman dari permukaan }< \\
10 \mathrm{~cm})\end{array}$ & & Min. 45 \\
\hline $\begin{array}{l}\text { Angularitas (kedalaman dari permukaan } \geq \\
10 \mathrm{~cm})\end{array}$ & SNI 03-6877-2002 & Min. 40 \\
\cline { 2 - 3 } & & \\
\hline
\end{tabular}

Sumber : Direktorat Jendral Bina Marga 2009

\section{Bahan Pengisi (Filler) Abu Batu}

Bahan pengisi (filler) adalah bahan pengisi rongga dalam campuran (void in mix) yang berbutir halus yang lolos saringan No.30 di mana persentase berat yang lolos saringan No.200 minimum 65\% (SKBI-2.4.26.1987).

Aspal

Aspal merupakan aspal keras hasil penyulingan minyak mentah dengan penetrasi 60/70. Fungsi aspal pada perkerasan jalan adalah:

- Sebagai bahan pengikat pada agregat agar tidak lepas dari permukaan jalan akibat lalu lintas.

- Sebagai bahan pengisi ruang yang kosong antara agregat kasar, agregat halus dan filler.

- Sebagai lapis resap pengikat (prime coat).

\section{Abu Vulkanik Sinabung}

Gunung Sinabung dan Gunung Sibayak adalah dua gunung berapi aktif di Sumatera Utara dan menjadi puncak tertinggi ke 2 di provinsi tersebut dengan ketinggian $2.451 \mathrm{~m}$. Gunung ini tidak pernah tercatat meletus sejak tahun 1600 , tetapi mendadak aktif kembali dengan meletus pada tahun 2010. Letusan terakhir gunung ini terjadi sejak 19 Februari 2018 dan berlangsung hingga kini. (Sumber: Dr. Surono, Kepala Pusat Vulkanologi dan Mitigasi Bencana Geologi (PVBMG) Badan Geologi). Beberapa aktivitas Gunung Sinabung dalam beberapa periode terakhir ini dengan perubahan yang terjadi di sekitar gunung tersebut setelah aktifitas gunung meletus (lihat pada Gambar 3 dan 4). 

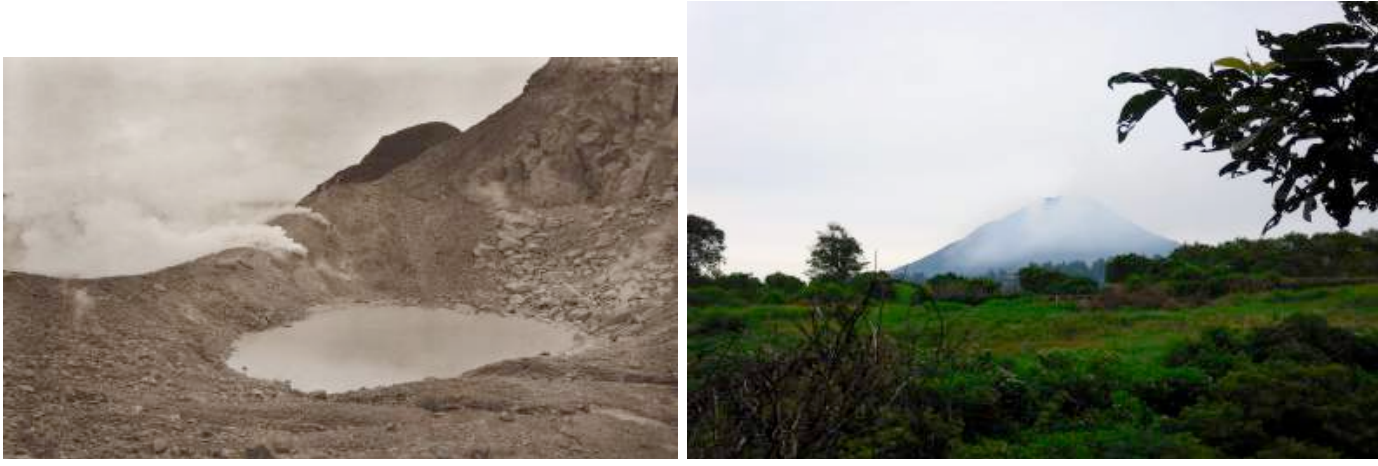

Gambar 3. Danau Kawah Gunung Sinabung 1920 (kiri); Gunung Sinabung 2010 (kanan)
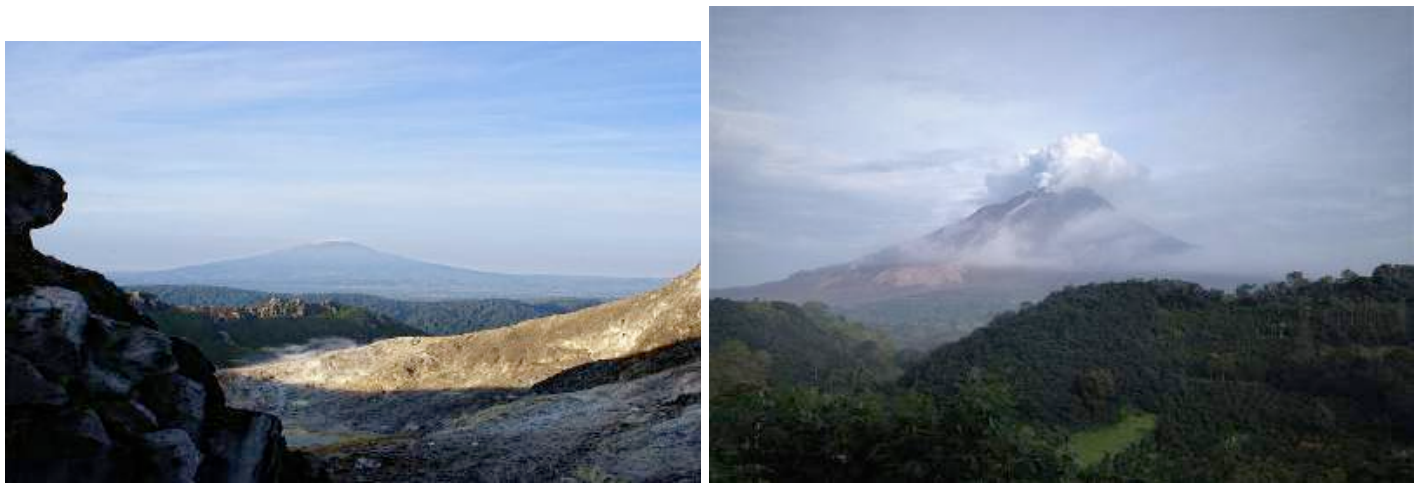

Gambar 4. Gunung Sinabung Maret 2010 (kiri); setelah erupsi 2014 (kanan)

Ciri-ciri fisik abu Sinabung ialah berwarna abu-abu merah, tidak berbau, berukuran kecil 100 mesh. Berdasarkan pengujian tugas akhir Fanny Siregar (2009), kandungan kimia abu batu dan abu vulkanik Sinabung adalah seperti tertera pada tabel berikut ini.

Tabel 2. Perbandingan Kandungan Kimia antara Abu Batu dan Abu Vulkanik Sinabung

\begin{tabular}{|l|l|l|l|}
\hline No. & Parameter & Abu Batu & Abu Vulkanik Sinabung \\
\hline 1. & Silika $(\mathrm{Si})$ & $57,30 \%$ & $73,742 \%$ \\
\hline 2. & Besi $(\mathrm{Fe})$ & $5,47 \%$ & $0,0724 \%$ \\
\hline 3. & Aluminium $(\mathrm{Al})$ & $26,05 \%$ & $7,0488 \%$ \\
\hline 4. & Kalsium $(\mathrm{Ca})$ & $1,37 \%$ & $0,74 \%$ \\
\hline 5. & Magnesium $(\mathrm{Mg})$ & $0,34 \%$ & $0,123 \%$ \\
\hline 6. & Kadar Air & $1,475 \%$ & $4,97 \%$ \\
\hline
\end{tabular}

\section{Kadar Aspal Campuran}

Kadar aspal campuran merupakan kadar aspal efektif (b') ditambah dengan kehilangan aspal akibat penyerapan agregat $(\Delta b)$.

$\mathrm{b}=\mathrm{b}^{\prime}+\Delta \mathrm{b}$

Dimana:

$\mathrm{b} \quad=$ total kadar aspal campuran,

b' = kadar aspal efektif, dan

$\Delta \mathrm{b} \quad=$ aspal yang diserap oleh agregat.

\section{Perencanaan Campuran}

Lapisan aspal yang baik memiliki nilai stabilitas, durabilitas, fleksibilitas dan tahanan geser yang baik. Sehingga, campuran aspal sebaiknya memiliki: 
$\checkmark$ Kadar aspal cukup memberikan kelenturan,

$\checkmark$ Stabilitas mampu memikul beban sehingga tak terjadi deformasi yang merusak,

$\checkmark$ Kadar rongga memberikan pemadatan tambahan akibat beban berulang dan flow dari aspal,

$\checkmark$ Memberikan kemudahan kerja sehingga tak terjadi segregasi,

$\checkmark$ Menghasilkan campuran lapis perkerasan yang sesuai dengan persyaratan.

Pembuatan campuran harus mengikuti tahapan berikut:

a Memilih gradasi dan agregat yang dipakai,

b Menentukan porsi tiap-tiap agregat sehingga mendapatkan gradasi yang diinginkan,

c Melakukan pengujian Marshall (kadar aspal optimum, stabilitas, flow dan quotient).

\section{Parameter Pengujian}

Metode Marshall diperkenalkan oleh Bruce Marshall seorang insinyur yang bekerja pada Missipi State Highway Department. Kemudian metode ini dikembangkan oleh U.S. Corps of Engineers dan para ahli lainnya.

\section{Kepadatan (Bulk Density)}

$$
\text { Kepadatan }=\frac{\mathrm{A}}{\mathrm{B}-\mathrm{C}}
$$

Dimana : $\mathrm{A}=$ berat sampel kering/weight of dry's sample in air (gram), $\mathrm{B}=$ berat sampel jenuh permukaan/ weight of SSD's sample (gram), dan $\mathrm{C}=$ berat sampel dalam air/ weight of sample in water (gram) Rongga Udara dalam Campuran (Voids In Mix/VIM)

$$
\mathrm{VIM}=\frac{\mathrm{Gsm}-\mathrm{Gmb}}{\mathrm{Gsm}} \quad \mathrm{VIM}=\frac{\mathrm{Gsm}-\mathrm{Gmb}}{\mathrm{Gsm}} \times 100 \%
$$

Dimana: Gsm = berat jenis maksimum teoritis campuran $\left(\mathrm{gr} / \mathrm{cm}^{3}\right) ; \mathrm{Gmb}=$ berat jenis Bulk benda uji $\left(\mathrm{gr} / \mathrm{cm}^{3}\right)$.

RSNI M 01-2003 mensyaratkan batas harga rongga udara dalam campuran (VIM) untuk perkerasan lapis aspal beton adalah antara 3\% - 5\%.

Rongga Dalam Agregat (Voids In Mineral Aggregate/VMA)

$$
V M A=100 \%-\frac{G m b \times P a}{G s b}
$$

Dimana : $\mathrm{Gmb}=$ rata-rata berat jenis bulk benda uji $\left(\mathrm{gr} / \mathrm{cm}^{3}\right) ; \mathrm{Gsb}=$ rata-rata berat jenis bulk total agregat $\left(\mathrm{gr} / \mathrm{cm}^{3}\right)$, dan $\mathrm{Pa}=$ persen agregat.

\section{Rongga Terisi Aspal (Voids Filled With Asphalt/VFA)}

$$
\text { VFA }=\frac{\text { Volume Asphalt Coment }}{\text { Volume Pori pada Agregat }} \times 100 \%
$$

Menurut "Spesifikasi RSNI M 01-2003" untuk lapisan aus, besarnya persentase rongga terisi aspal (VFA) adalah min $65 \%$.

Stabilitas (Stability)

Menurut RSNI M 01-2003 besarnya nilai stabilitas dalam campuran untuk perkerasan lapis aspal beton minimum $550 \mathrm{~kg}$.

Kelelehan (Flow)

Menurut RSNI M 01-2003 batas flow yang diijinkan untuk lalu lintas berat adalah antara 2 $\mathrm{mm}-4 \mathrm{~mm}$. 
Kekakuan (Quotient)

$$
\text { Quotient }=\frac{\text { Stability }}{\text { Flow }}
$$

Menurut RSNI M 01-2003 batas harga kekakuan adalah min 200 kg/mm s/d 350 kg/mm.

\section{Metode Penelitian}

\section{Pengujian Kadar Aspal Optimum}

Diawali desain proporsi Agregat: CA (25\%) : MA (55\%) : FA (15\%) : Filler (5\%) dengan perlakuan kadar aspal yakni 4,0\%, 4,5\%, 5,0\%, 5,5\%, 6,0\%, 6,5\%, 7,0\% dari jumlah material yang digunakan untuk setiap sampel. Penentuan temperatur campuran dan pemadatan adalah $150^{\circ} \mathrm{C}$ dan suhu pemadatan $140^{\circ} \mathrm{C}$. Kemudian dipadatkan di dalam cetakan dan dirojok dengan spatula sebanyak 10 kali di bagian tengah serta 15 kali di bagian pinggir, setelah dirojok campuran diratakan sehingga berbentuk sedikit cembung dan dimasukkan kembali kertas saring pada bagian atas sampel. Selanjutnya proses penumbukan sebanyak 75 kali.

\section{Metode Pengujian Sampel}

Prosedur pengujian menurut RSNI M-01-2003 tentang Metode Pengujian Campuran Beraspal Panas dengan Alat Marshall. Pengujian ini terdiri dari dua bagian yaitu : penentuan berat jenis dan berat isi (Bulk specific Gravity) dan pengujian stabilitas dan kelelehan (flow).

\section{Pengujian Stabilitas dan Flow}

Setelah bulk specific gravity sampel diperoleh maka dilanjutkan dengan pengujian stabilitas dan flow dengan langkah-langkah sebagai berikut:

a. Sampel direndam water bath selama 30 menit pada suhu $60^{\circ} \mathrm{C}\left( \pm 1^{0} \mathrm{C}\right)$.

b. Setelah itu, sampel dikeluarkan dan langsung diletakkan pada segmen bawah kepala penekan.

c. Segmen atas dipasang di atas benda uji, segmen penekan tersebut diletakkan di atas mesin penguji serta dipasang dial pembacaan flow pada kedudukannya dan dinolkan beserta dial stabilitas.

d. Sebelum pembebanan diberikan, kepala penekan beserta benda uji dinaikkan hingga menyentuh alas cincin penguji, kemudian nolkan kembali dial pembacaan flow dan stabilitas.

e. Setelah kedua dial tersebut pada posisi nol maka dilakukan pembebanan dengan kecepatan tetap $\pm 50 \mathrm{~mm} /$ menit sampai pembebanan maksimum tercapai atau harga stabilitas menurun, hal ini dapat dilihat pada pembacaan stabilitas. Nilai stabilitas maksimum tersebut dicatat beserta nilai flow yang ditunjukkan oleh dial pembacaan flow pada saat nilai stabilitas tercapai.

f. Pengujian berikutnya dilakukan seperti hal di atas.

\section{Analisis dan Pembahasan}

Grafik berikut menunjukkan spesifikasi batas atas dan batas bawah yang diisyaratkan serta desain agregat yang digunakan dalam penelitian ini. 


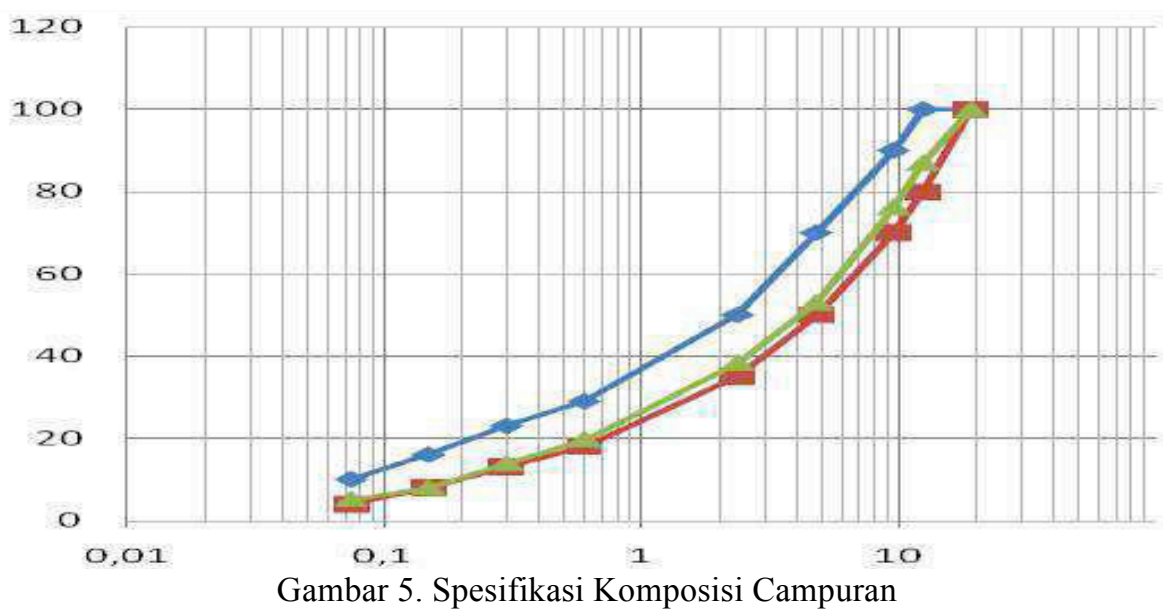

\section{Nilai Keausan dan Kadar Lumpur Agregat}

Hasil laboratorium menunjukkan bahwa Nilai keausan $=18,34 \%$, kadar lumpur pasir biasa $3,4 \%$ dan pasir vulkanik Sinabung 6,4\%. Dengan kadar lumpur pasir vulkanik Sinabung adalah sebesar 6,4\% > 5\% ketentuan Bina Marga artinya tidak memenuhi standar. Dalam penelitian ini di lembar berikut akan disajikan bagaimana usaha agar pasir Sinabung dapat dimanfaatkan menjadi bahan agregat halus.

\section{Nilai Spesific Gravity (U) dan Effective Spesific Gravity (V)}

Hasil pengujian menghasilkan Bulk Spesific Gravity $(\mathrm{U})=2,7592 \mathrm{gr} / \mathrm{cm}^{3}$, Effective Spesific Gravity (V) = 2,8312 gr/ $\mathrm{cm}^{3}$ untuk filler abu batu, sedangkan Bulck Spesific Gravity (U) dan Effective Spesific Gravity (V) dengan Filler Abu Vulkanik Sinabung 2,7282 $\mathrm{gr} / \mathrm{cm}^{3}$ dan $2,8002 \mathrm{gr} / \mathrm{cm}^{3}$.

\section{Pengujian Marshall}

Pengujian Marshall untuk mendapatkan kadar aspal optimum berdasarkan nilai: stability, flow, quotient, voids in mix (VIM), voids in mineral aggregate (VMA), voids filled with bitumen (VFB).

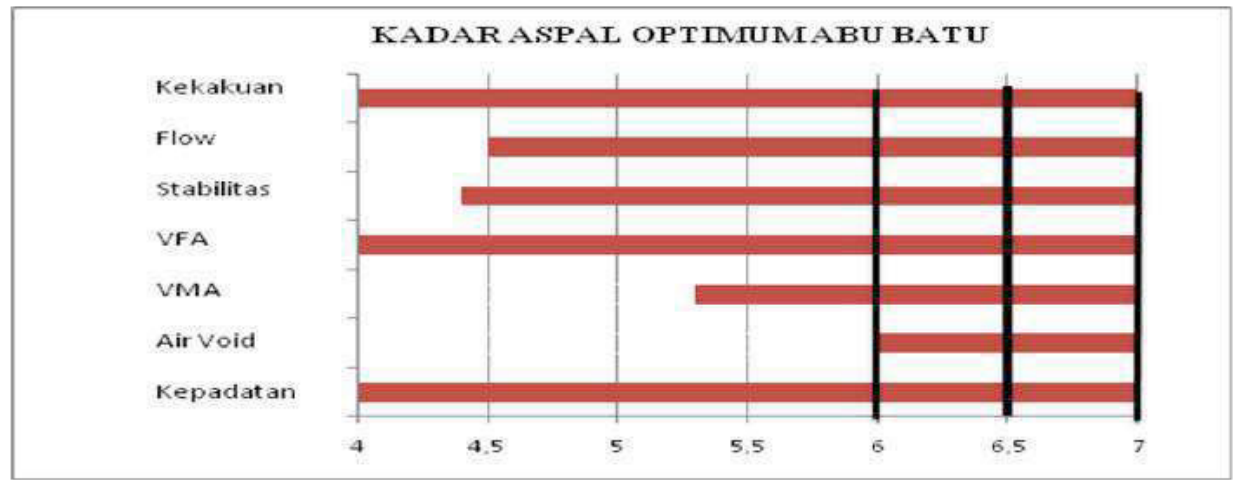

Gambar 6. Diagram Batang Kadar Aspal Optimum Abu Batu 


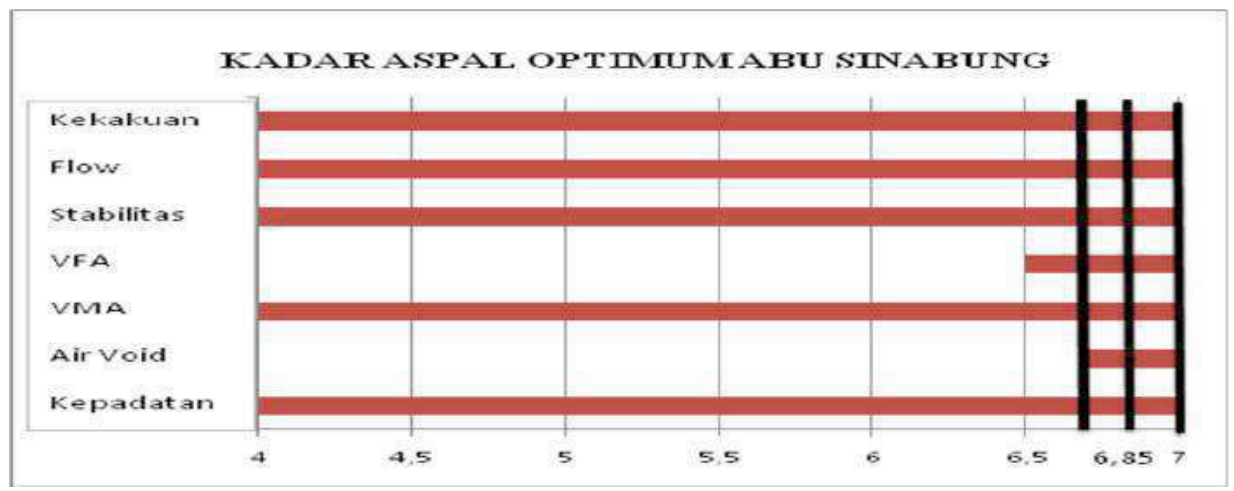

Gambar 7. Diagram Batang Kadar Aspal Optimum Abu Vulkanik Sinabung

Berdasarkan Gambar 6 dan Gambar 7 di atas nilai kadar aspal optimum (KAO) dengan filler abu batu $=6,5 \%$ sedangkan KAO dengan filler abu vulkanik $=6,85 \%$. Selanjutnya, abu batu dan abu vulkanik digunakan sebagai bahan pengisi dalam campuran dengan 7 perlakuan kombinasi seperti pada Tabel berikut.

Tabel 3. Perhitungan kadar campuran filler dalam aspal optimum

\begin{tabular}{|c|c|c|c|c|c|}
\hline \multirow[b]{2}{*}{ Perlakuan } & \multicolumn{2}{|c|}{ Ratio Spilt } & \multirow[b]{2}{*}{$\begin{array}{l}\text { Berat Total } \\
\text { (gr) }\end{array}$} & \multicolumn{2}{|c|}{ Ratio Berat Material (gr) } \\
\hline & $\begin{array}{l}\text { Abu } \\
\text { Vulkanik }\end{array}$ & Abu Batu & & $\begin{array}{l}\text { Abu } \\
\text { Vulkanik }\end{array}$ & Abu Batu \\
\hline 1 & 0 & 100 & 60 & 0 & 60 \\
\hline 2 & 50 & 50 & 60 & 30 & 30 \\
\hline 3 & 60 & 40 & 60 & 36 & 24 \\
\hline 4 & 70 & 30 & 60 & 42 & 18 \\
\hline 5 & 80 & 20 & 60 & 48 & 12 \\
\hline 6 & 90 & 10 & 60 & 54 & 6 \\
\hline 7 & 100 & 0 & 60 & 60 & 0 \\
\hline
\end{tabular}

Berikutnya adalah penyelidikan kadar aspal optimum menggunakan filler gabungan (Abu Vulkanik Sinabung dengan abu batu). Desain campuran agregat CA (25\%) : MA (55\%): FA $(15 \%)$ : Filler $(5 \%=$ sesuai perlakuan rencana). Setiap perlakuan dihitung Bulk Specific Gravity (U) dan Effective Specific Gravity (V). Hasil parameter Marshall dapat dilihat pada gambar-gambar berikut ini.
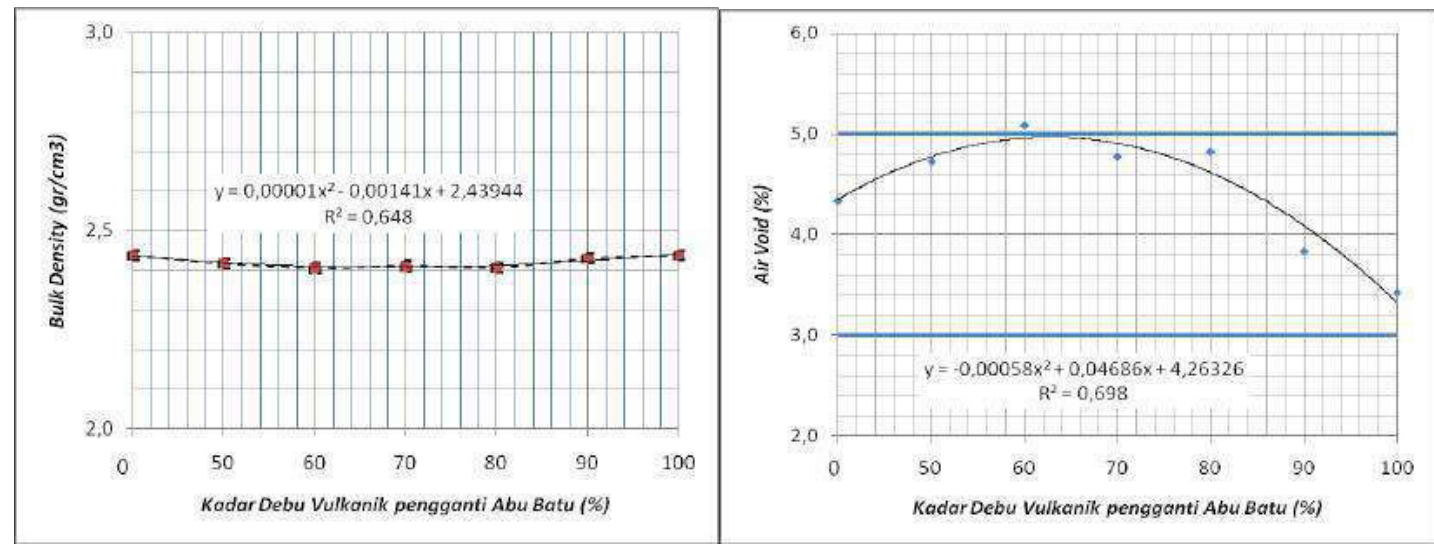

Gambar 8. Hubungan Kepadatan dan Kadar Aspal (kiri); Hubungan air void dan kadar aspal (kanan) 

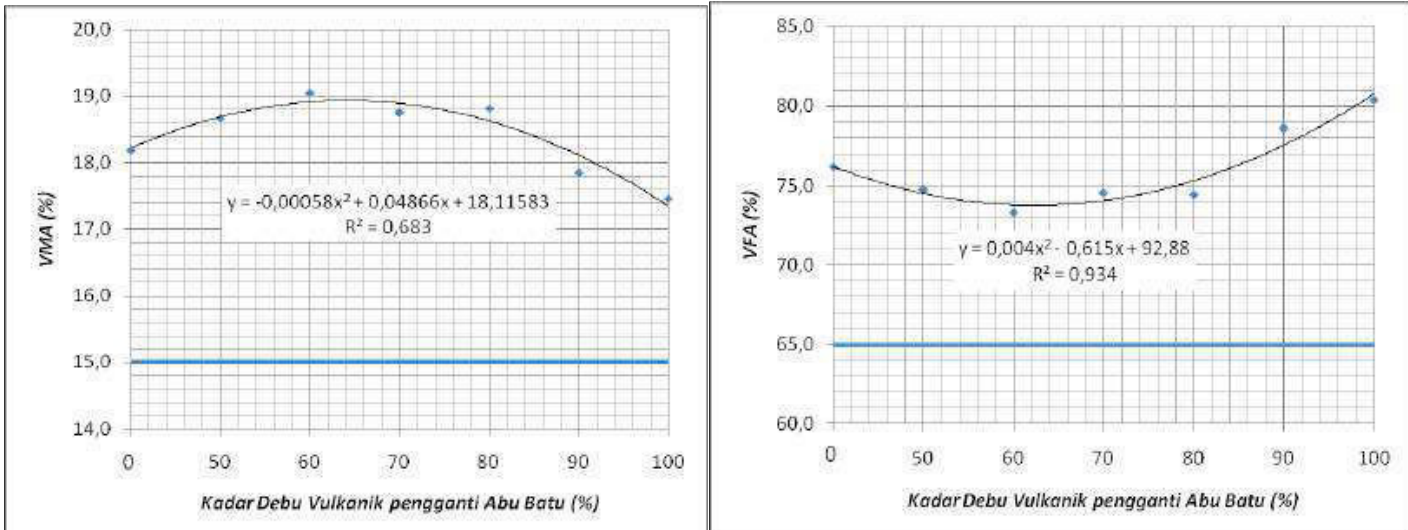

Gambar 9. Hubungan VMA dan Kadar Aspal (kiri) ; Hubungan VFA dan Kadar Aspal (kanan)
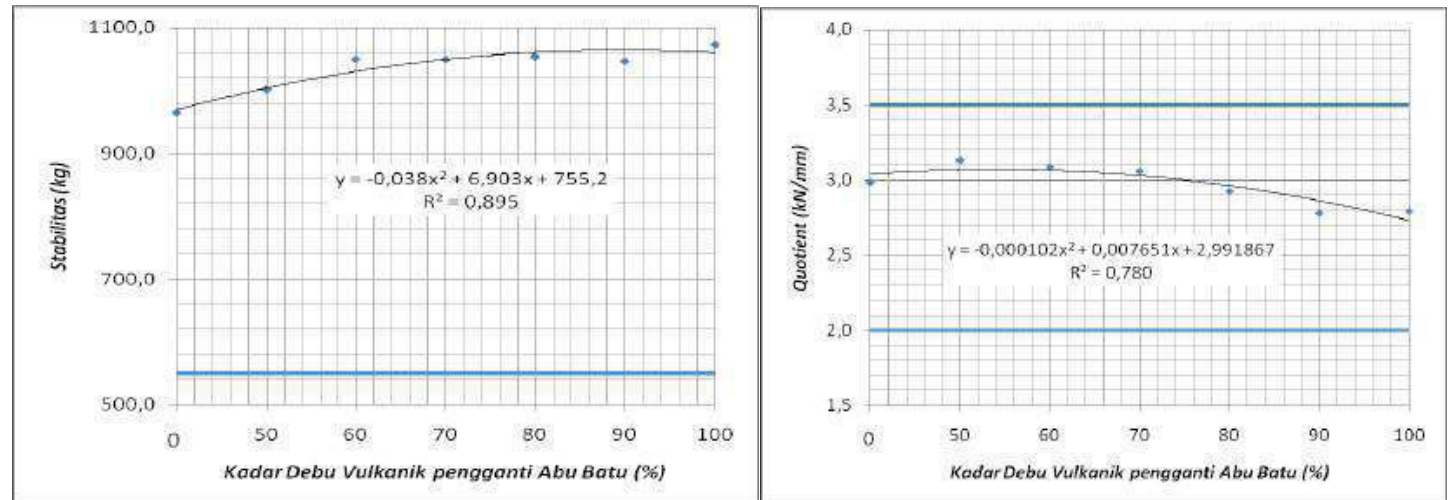

Gambar 11. Hubungan Stabilitas dan Kadar Aspal (kiri); Hubungan Kekakuan dan Kadar Aspal (kanan)

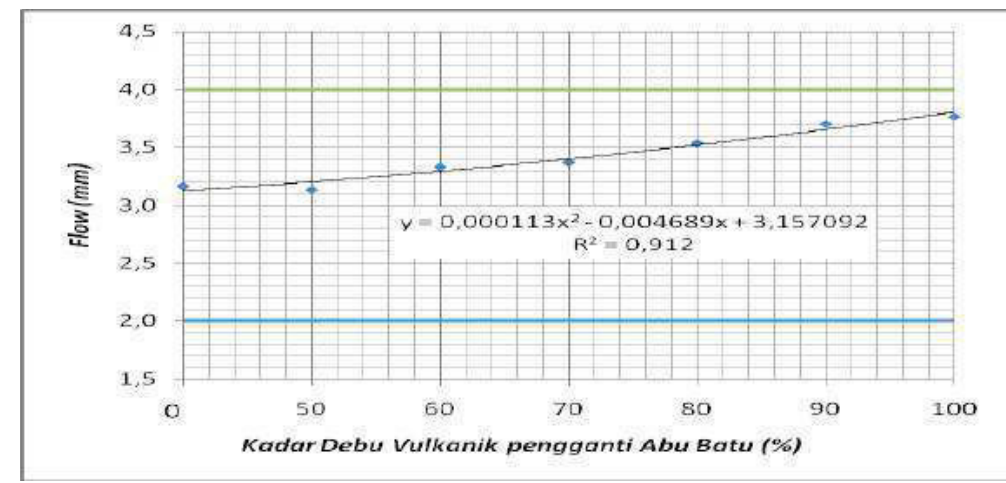

Gambar 12. Hubungan Kelelehan Dengan Kadar Aspal

Berdasarkan gambar di atas diperoleh hasil pengujian Marshall adalah seperti pada tabel berikut ini. Dari 7 perlakuan perbandingan penggunaan abu batu dan abu vulkanik memberikan hasil seperti pada Tabel 4 , bahwa kombinasi yang baik untuk campuran aspal beton adalah $50 \%$ abu vulkanik dan $50 \%$ abu batu. 
Tabel 4. Hasil Pengujian Marshall dengan Kombinasi Abu Vulkanik dan Abu Batu

\begin{tabular}{|l|l|l|l|l|l|l|l|l|}
\hline \multicolumn{2}{|c|}{ Kombinasi } & \multicolumn{7}{c|}{ Kadar Pengujian Marshall } \\
\hline $\begin{array}{l}\text { Abu batu } \\
(\%)\end{array}$ & $\begin{array}{l}\text { Abu } \\
\text { Sinabung } \\
(\%)\end{array}$ & $\begin{array}{l}\text { Bulk } \\
\text { Density } \\
\left(\mathrm{gr} / \mathrm{cm}^{3}\right)\end{array}$ & $\begin{array}{l}\text { Air } \\
\text { Void }\end{array}$ & $\begin{array}{l}\text { \% } \\
\text { VMA }\end{array}$ & \% VFA & $\begin{array}{l}\text { Stability } \\
(\mathrm{kg})\end{array}$ & $\begin{array}{l}\text { Flow } \\
(\mathrm{mm})\end{array}$ & $\begin{array}{l}\text { Quotient } \\
(\mathrm{kN} / \mathrm{mm})\end{array}$ \\
\hline 0 & 100 & 2,438 & 4,336 & 18,189 & 76,169 & 964,478 & 3,167 & 2,987 \\
\hline 50 & 50 & 2,416 & 4,724 & 18,667 & 74,706 & 1000,92 & 3,133 & 3,132 \\
\hline 60 & 40 & 2,405 & 5,033 & 19,045 & 73,311 & 1049,587 & 3,333 & 3,088 \\
\hline 70 & 30 & 2,411 & 4,771 & 18,750 & 74,561 & 1049,838 & 3,367 & 3,057 \\
\hline 80 & 20 & 2,407 & 4,825 & 18,823 & 74,370 & 1053,943 & 3,533 & 2,924 \\
\hline 90 & 10 & 2,430 & 3,828 & 17,845 & 78,581 & 1047,399 & 3,700 & 2,777 \\
\hline 100 & 0 & 2,438 & 3,423 & 17,458 & 60,392 & 1072,760 & 3,767 & 2,792 \\
\hline
\end{tabular}

\section{Pemanfaatan Pasir Gunung Sinabung Sebagai Agregat Halus (Fine Aggregate/FA)}

Proporsional desain campuran tetap sama seperti yakni: CA (25\%) : MA (55\%) : FA (15\% berupa gabungan pasir vulkanik dengan pasir biasa) : Filler (5\%). Rasio split antara pasir vulkanik terhadap pasir biasa dapat dilihat pada Tabel 6 . Berikut.

Tabel 5. Perhitungan Kadar Penggantian Fine Agregat Dalam Aspal Optimum

\begin{tabular}{|c|c|c|c|c|c|c|c|}
\hline \multirow{2}{*}{ Perlakuan } & \multicolumn{2}{|c|}{ Ratio Spilt } & \multicolumn{2}{|c|}{$\begin{array}{c}\text { Ratio Berat Material } \\
\text { (gr) }\end{array}$} & $\begin{array}{c}\text { Berat } \\
\text { Total } \\
(\mathrm{gr})\end{array}$ & $\begin{array}{c}\text { Bulk } \\
\text { Specific } \\
\text { Gravity }\end{array}$ & $\begin{array}{c}\text { Effective } \\
\text { Specific } \\
\text { Gravity }\end{array}$ \\
\cline { 2 - 8 } & $\begin{array}{c}\text { Pasir } \\
\text { Vulkanik }\end{array}$ & $\begin{array}{c}\text { Pasir } \\
\text { Biasa }\end{array}$ & $\begin{array}{c}\text { Pasir } \\
\text { Vulkanik }\end{array}$ & Pasir Biasa & & & \\
\hline 1 & 25 & 75 & 15 & 45 & 60 & 2,7304 & 2,8029 \\
\hline 2 & 50 & 50 & 30 & 30 & 60 & 2,7327 & 2,8057 \\
\hline 3 & 75 & 25 & 45 & 15 & 60 & 2,7349 & 2,8085 \\
\hline 4 & 100 & 0 & 60 & 0 & 60 & 2,7372 & 2,8113 \\
\hline
\end{tabular}

Hasil pengujian Marshall Test benda uji dengan variasi penggantian Fine Agregat dapat dilihat pada Tabel 6. di bawah.

Tabel 6. Hasil Pengujian Marshall

\begin{tabular}{|c|c|c|c|c|c|c|c|c|}
\hline Perlakuan & $\begin{array}{c}\text { Bulk } \\
\text { Density } \\
\left(\mathrm{gr} / \mathrm{cm}^{3}\right)\end{array}$ & $\begin{array}{c}\text { Air } \\
\text { Void }\end{array}$ & $\begin{array}{c}\% \\
\text { VMA }\end{array}$ & $\begin{array}{c}\% \\
\text { VFA }\end{array}$ & $\begin{array}{c}\text { Stability } \\
(\mathrm{kg})\end{array}$ & $\begin{array}{c}\text { Flow } \\
(\mathrm{mm})\end{array}$ & $\begin{array}{c}\text { Quotient } \\
(\mathrm{kN} / \mathrm{mm})\end{array}$ & Keterangan \\
\hline 1 & 2,251 & 10,898 & 25,025 & 56,490 & 699,794 & 5,467 & 1,254 & $\begin{array}{c}\text { Tidak } \\
\text { Memenuhi }\end{array}$ \\
\hline 2 & 2,333 & 7,748 & 21,966 & 64,769 & 606,673 & 5,133 & 1,158 & $\begin{array}{c}\text { Tidak } \\
\text { Memenuhi }\end{array}$ \\
\hline 3 & 2,377 & 6,088 & 20,399 & 70,606 & 684,811 & 5,333 & 1,259 & $\begin{array}{c}\text { Tidak } \\
\text { Memenuhi }\end{array}$ \\
\hline 4 & 2,370 & 6,426 & 20,828 & 69,196 & 825,273 & 5,567 & 1,454 & $\begin{array}{c}\text { Tidak } \\
\text { Memenuhi }\end{array}$ \\
\hline \multicolumn{2}{|c|}{ Spesifikasi } & $3-5$ & $>15$ & $>65$ & $>550$ & $2-4$ & $2-3,5$ & \\
\hline
\end{tabular}

Gambar 13 menunjukkan nilai kepadatan $2,247 \mathrm{gr} / \mathrm{cm}^{3}$ hingga 2,322 $\mathrm{gr} / \mathrm{cm}^{3}$ dan $\mathrm{R}^{2}=0,813$ yang berarti bahwa sebarannya sebesar $81,3 \%$. Berdasarkan SNI, untuk kepadatan hasilnya tidak ada atau dalam kata lain adalah bebas yang artinya bahwa kepadatannya memenuhi dari kombinasi 25\% hingga 100\%. Selanjutnya, menunjukkan nilai Air Void-nya adalah $4,35 \%$ hingga $4,97 \%$ dan nilai $\mathrm{R}^{2}=0,801$ yang berarti bahwa sebarannya sebesar $80,1 \%$. Berdasarkan SNI, untuk Air Void adalah 3\% s/d 5\% memenuhi, dari kombinasi 80\% hingga $100 \%$. 

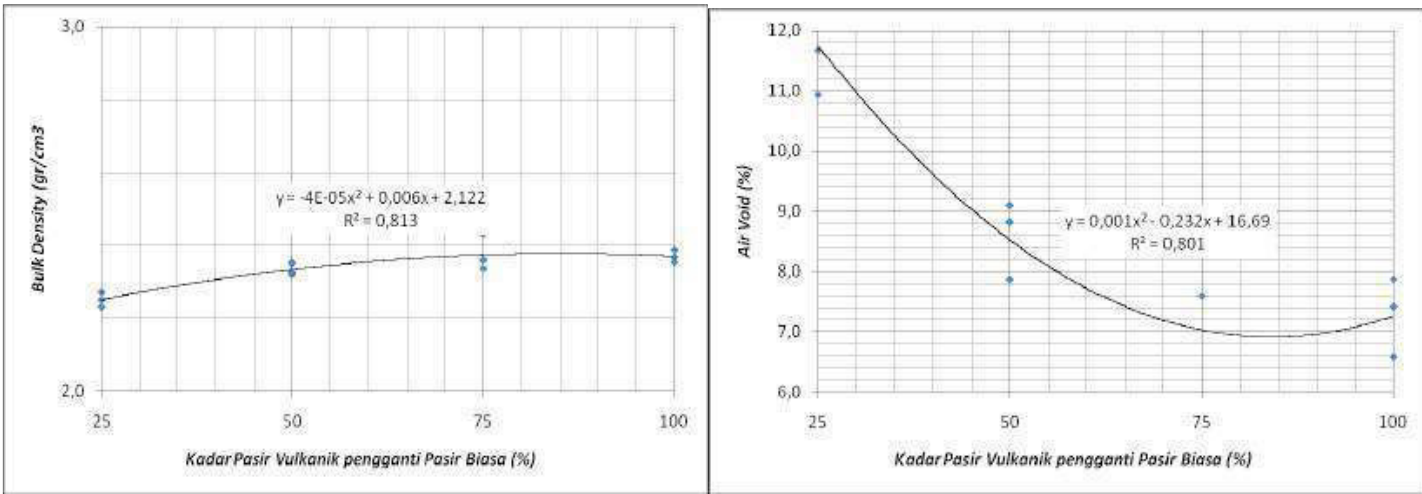

Gambar 13. Hubungan Kepadatan dan Kadar Aspal (kiri); Hubungan air void dan Kadar aspal (kanan)
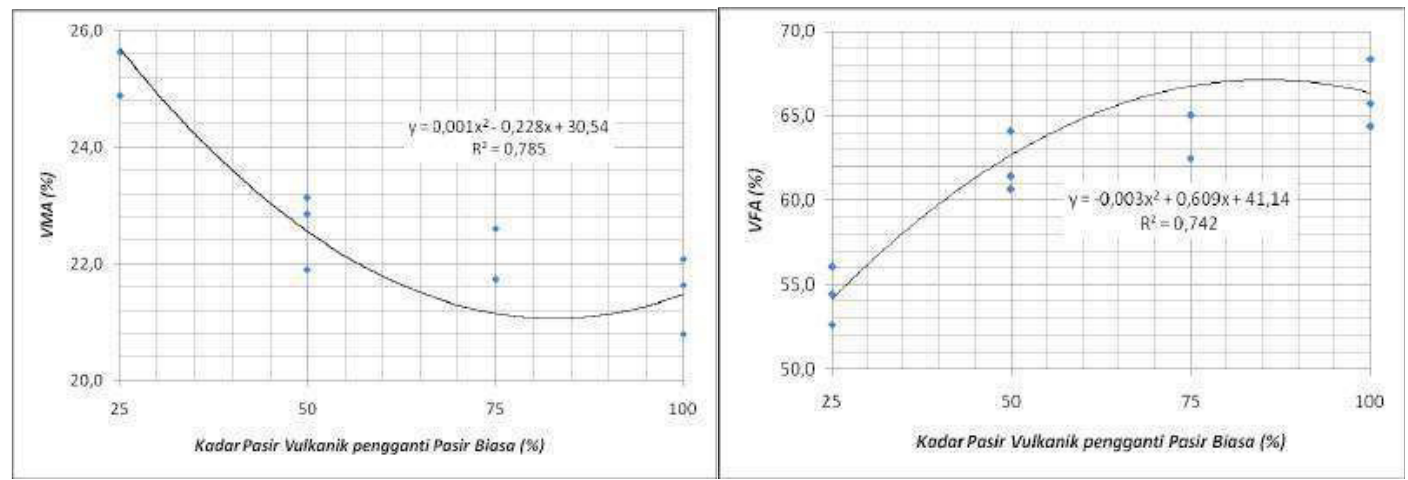

Gambar 14. Hubungan VMA dan Kadar Aspal (kiri); Hubungan VFA dan Kadar Aspal (kanan)

Gambar 14 di atas menunjukkan nilai Void In Mineral Aggregate minimum 18,78\% dan Void In Mineral Aggregate maksimumnya 24,94\% dan nilai $\mathrm{R}^{2}=0,785$ yang berarti bahwa sebarannya sebesar 78,5\%. Berdasarkan SNI, untuk Void In Mineral Aggregate syaratnya adalah $>15 \%$, dengan demikian Void In Mineral Aggregate memenuhi, baik dari kombinasi 25\% hingga 100\%. Selanjutnya, menunjukkan nilai Void Field With Asphalt minimum $65,785 \%$ dan Void Field With Asphalt maksimum 78,16\% serta nilai $\mathrm{R}^{2}=0,742$ yang berarti bahwa sebarannya sebesar 74,2\%. Berdasarkan SNI, Void Field With Asphalt syaratnya adalah $>65 \%$, maka dari grafik di atas dapat dilihat bahwa Void Field With Asphalt memenuhi, baik dari kombinasi $45 \%$ hingga $100 \%$.
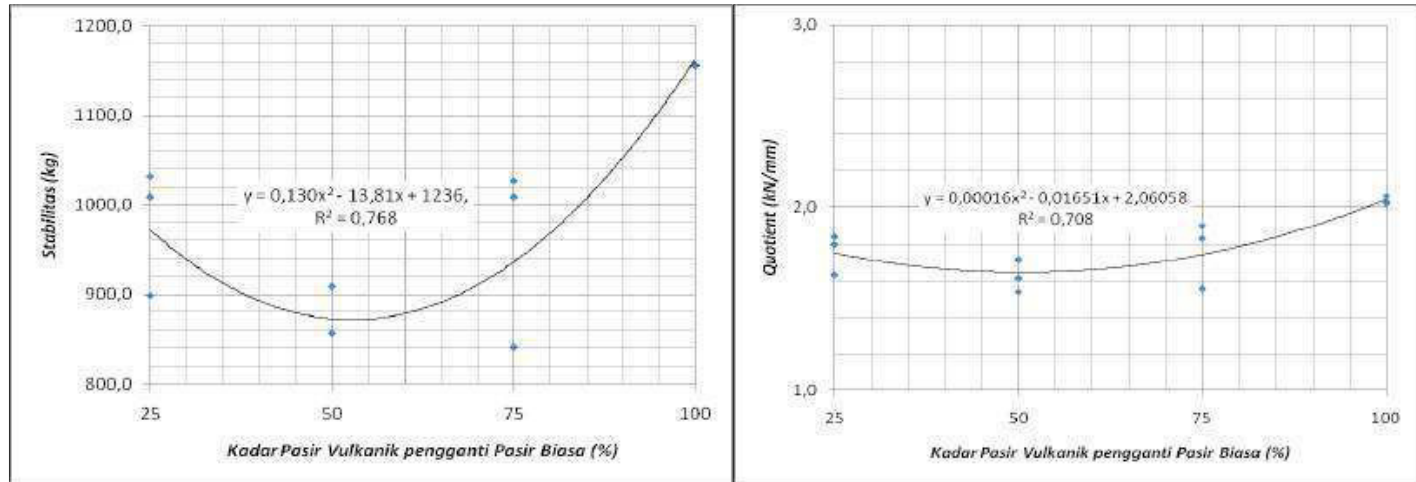

Gambar 15. Hubungan Stabilitas dan Kadar aspal (kiri); Hubungan Kekakuan dan Kadar Aspal (kanan) 
Gambar 15 di atas menunjukkan nilai Stabilitas minimum 694,025 kg dan Stabilitas maksimum $826,4 \mathrm{~kg}$ dan nilai $\mathrm{R}^{2}=0,768$ yang berarti bahwa sebarannya sebesar $76,8 \%$. Berdasarkan SNI, syarat Stabilitas adalah $>550 \mathrm{~kg}$. Sehingga berdasarkan grafik di atas dapat dilihat bahwa Stabilitasnya memenuhi kombinasi 25\% hingga 100\%. Selanjutnya, menunjukkan bahwa nilai $\mathrm{R}^{2}=0,708$ yang berarti bahwa sebarannya sebesar $70,8 \%$. Sehingga berdasarkan grafik di atas dapat dilihat bahwa Quotient tidak memenuhi pada kombinasi $25 \%$ hingga $100 \%$.

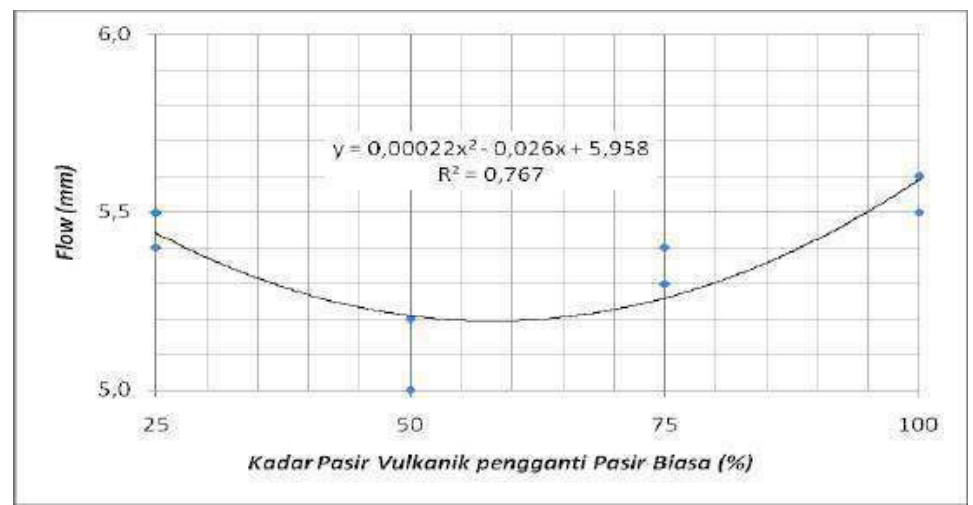

Gambar 16. Hubungan Kelelehan Dengan Kadar Aspal

Gambar 16 di atas menunjukkan bahwa nilai $\mathrm{R} 2=0,767$ yang berarti bahwa sebarannya sebesar 76,7\%. Dimana berdasarkan SNI maka untuk Flow syaratnya adalah $2 \mathrm{~mm} \mathrm{~s} / \mathrm{d} 4 \mathrm{~mm}$. Sehingga berdasarkan grafik di atas dapat dilihat bahwa flow tidak memenuhi, baik kombinasi $25 \%$ hingga $100 \%$.

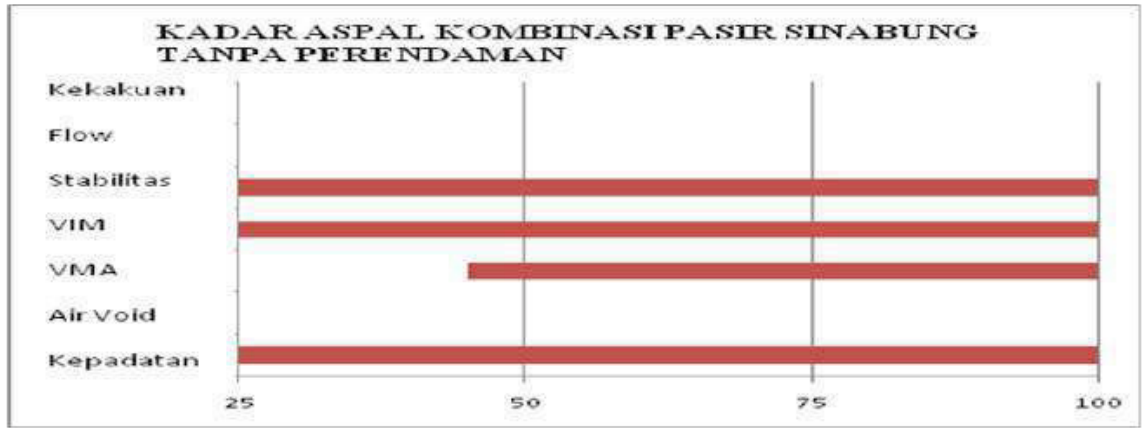

Gambar 17. Nilai Parameter Pengujian dengan Kadar Aspal Kombinasi Pasir Sinabung Tanpa Perendaman

Gambar 17 menunjukkan bahwa nilai kekakuan, flow, serta air void pada benda uji menggunakan agregat halus dari pasir Sinabung berada pada syarat yang telah diterapkan oleh SNI, maka dalam penelitian ini diambil kesimpulan sementara bahwa pasir Sinabung tidak layak digunakan sebagai bahan konstruksi jalan raya jika pasir tersebut baru 2 hari disemburkan akibat aktivitas gunung Sinabung. Selanjutnya dicoba dengan dengan perendam selama 7 hari. Hasilnya dapat dilihat pada gambar berikut ini. 



Gambar 18. Hubungan Kepadatan Aspal dan Kadar Aspal (kiri); Hubungan Rongga udara dan Kadar aspal (kanan)

Gambar 18. di atas menunjukkan nilai kepadatannya adalah 2,429 gr/ $\mathrm{cm}^{3}$ hingga 2,279 $\mathrm{gr} / \mathrm{cm}^{3}$ dan nilai $\mathrm{R}^{2}=0,730$ (artinya bahwa sebarannya sebesar $73,0 \%$ ). Berdasarkan SNI, kepadatan hasilnya tidak ada atau dalam kata lain adalah bebas, artinya adalah kepadatannya memenuhi dari kombinasi $25 \%$ hingga $100 \%$. Selanjutnya, pada gambar di atas dapat dilihat bahwa nilai Air Voidnya adalah 3,613\% hingga 3,079\% dan nilai $\mathrm{R}^{2}=0,743$ (artinya bahwa sebarannya sebesar 74,3\%), maka berdasarkan SNI, Air Void adalah 3\% s/d 5\%. Sehingga berdasarkan grafik di atas dapat dilihat bahwa Air Void memenuhi pada kombinasi $25 \%$ hingga $31 \%$.
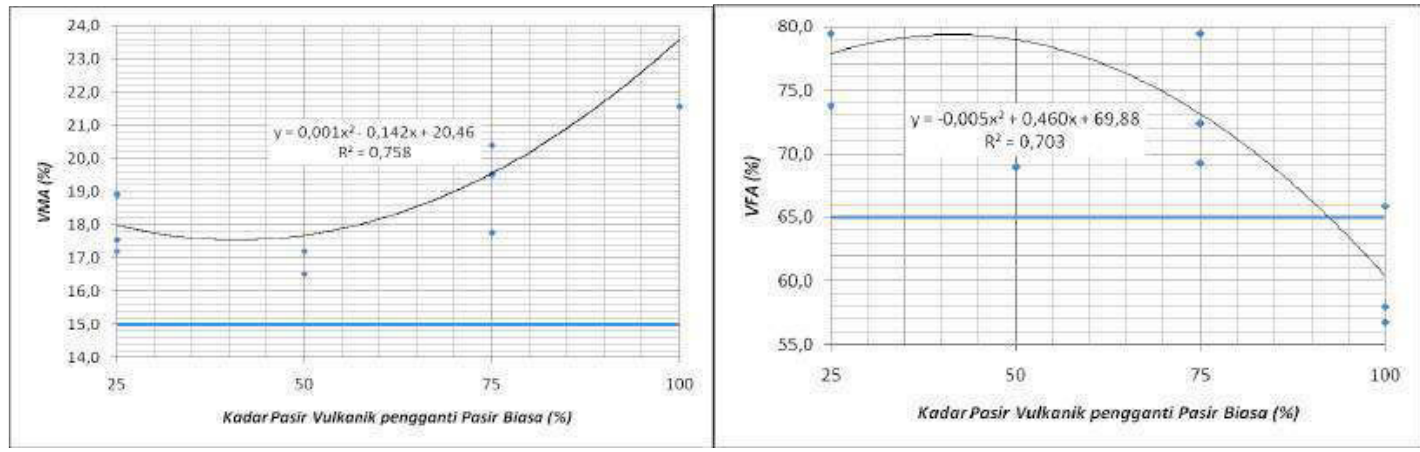

Gambar 19. Hubungan VMA dan Kadar Aspal (kiri); Hubungan VFA dan Kadar Aspal (kanan)

Gambar 19 di atas menunjukkan nilai Void In Mineral Aggregate minimum 16,26\% dan Void In Mineral Aggregate maksimum 17,535\% serta nilai $\mathrm{R}^{2}=0,758$ (artinya bahwa sebarannya sebesar 75,8\%). Berdasarkan SNI, syarat Void In Mineral Aggregate adalah > 15\%, maka berdasarkan grafik di atas Void In Mineral Aggregate memenuhi pada kombinasi $25 \%$ hingga $100 \%$. Selanjutnya, gambar di atas menunjukkan bahwa nilai Void Field With Asphalt minimum 65,88\% dan Void Field With Asphalt maksimum 78,225\% serta nilai $\mathrm{R}^{2}=$ 0,703 (artinya bahwa sebarannya sebesar 70,3\%). Berdasarkan SNI syarat Void Field With Asphalt adalah $>65 \%$, maka berdasarkan grafik di atas Void Field With Asphalt memenuhi pada kombinasi $25 \%$ hingga $100 \%$.

Gambar 20 berikut ini menunjukkan nilai Stabilitas minimum 1043,25 kg dan Stabilitas maksimum $840 \mathrm{~kg}$ serta nilai $\mathrm{R}^{2}=0,517$ (artinya sebarannya sebesar 51,7\%). Berdasarkan SNI syarat Stabilitas adalah $>550 \mathrm{~kg}$. Sehingga berdasarkan grafik di atas dapat dilihat bahwa Stabilitasnya memenuhi pada kombinasi $25 \%$ hingga $100 \%$. Selain itu, gambar tersebut menunjukkan nilai Quotient minimum 2,901 kN/mm dan Quotient maksimum 2,029 $\mathrm{kN} / \mathrm{mm}$ serta nilai $\mathrm{R}^{2}=0,828$ (artinya sebarannya sebesar $82,8 \%$ ). Berdasarkan SNI syarat 
Quotient minimal 2,5 kN/mm. Sehingga berdasarkan grafik di atas dapat dilihat bahwa Quotient memenuhi pada kombinasi 25\% hingga 65\%.
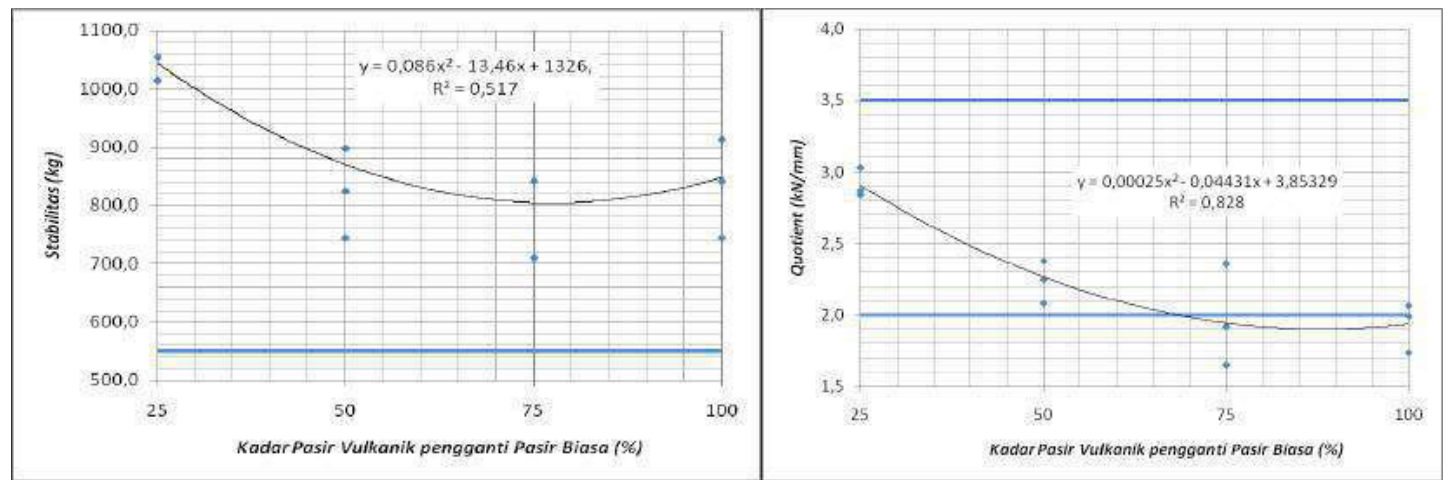

Gambar 20. Hubungan Stabilitas dan kadar aspal (kiri); Hubungan Kekakuan dan Kadar Aspal (kanan)

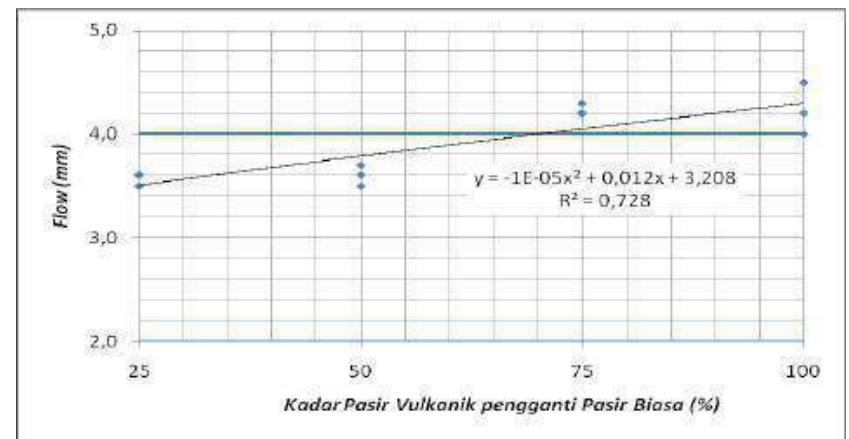

Gambar 21. Hubungan Kelelehan dengan Kadar Aspal

Gambar 21 di atas menunjukkan nilai Flow minimum 3,5018 mm dan Flow maksimum 4,009 $\mathrm{mm}$ dan nilai $\mathrm{R}^{2}=0,728$ (artinya sebarannya sebesar $72,8 \%$ ). Berdasarkan SNI, syarat Flow 2 $\mathrm{mm} \mathrm{s} / \mathrm{d} 4 \mathrm{~mm}$. Sehingga berdasarkan grafik di atas dapat dilihat bahwa Flow memenuhi, pada kombinasi $25 \%$ hingga $71 \%$.

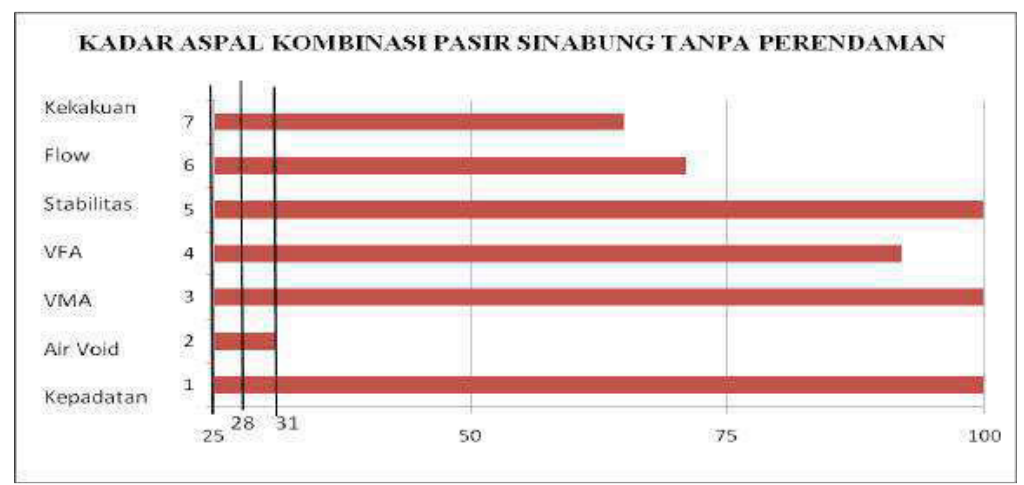

Gambar 22. Pengujian dengan Kadar Aspal Kombinasi Pasir Biasa dengan Pasir Sinabung dengan Perendaman 7 Hari

Berdasarkan hasil perhitungan dan grafik tersebut, kombinasi maksimum adalah $28 \%$ pasir Sinabung dan $72 \%$ pasir biasa dan nilai masingg-masing parameter Marshall disajikan pada Tabel 8. berikut. 
Tabel 7. Nilai Marshall Dengan Pasir Vulkanik Pada Perendaman 7 Hari

\begin{tabular}{|c|c|c|c|c|c|c|c|}
\hline Perlakuan & $\begin{array}{c}\text { Bulk Density } \\
\left(\mathrm{gr} / \mathrm{cm}^{3}\right)\end{array}$ & $\begin{array}{c}\text { Air Void } \\
(\%)\end{array}$ & $\begin{array}{c}\% \\
\text { VMA }\end{array}$ & $\%$ VFA & $\begin{array}{c}\text { Stability } \\
(\mathrm{kg})\end{array}$ & $\begin{array}{c}\text { Flow } \\
(\mathrm{mm})\end{array}$ & $\begin{array}{c}\text { Quotient } \\
(\mathrm{kN} / \mathrm{mm})\end{array}$ \\
\hline 1 & 2,450 & 3,940 & 17,884 & 78,097 & 1060,175 & 3,567 & 2,913 \\
\hline 2 & 2,450 & 3,993 & 18,028 & 78,483 & 821,851 & 3,600 & 2,235 \\
\hline 3 & 2,424 & 5,104 & 19,229 & 73,701 & 853,661 & 4,233 & 1,977 \\
\hline 4 & 2,314 & 9,497 & 23,713 & 60,210 & 832,417 & 4,233 & 1,928 \\
\hline \multicolumn{2}{|c|}{ Spesifikasi } & $3-5$ & $>15$ & $>65$ & $>550$ & $2-4$ & $2-3,5$ \\
\hline
\end{tabular}

Pada Tabel 7 di atas ditunjukkan bahwa dengan 4 (empat) perlakuan diperoleh nilai kepadatan mengalami penurunan dari perlakuan pertama sebesar $1060,175 \mathrm{~kg}$ menjadi sebesar 832,417 kg untuk perlakuan ke-4 (keempat). Hal ini berarti semakin banyak porsentase pasir Sinabung yang digunakan maka nilai kepadatan semakin menurun, yang menggambarkan bahwa campuran mengandung pori/rongga yang semakin luas sehingga menyebabkan kandungan kadar air dan rongga udara dalam agregat semakin meningkat dan secara tidak langsung akan mempengaruhi nilai stabilitas, Sebaliknya nilai flow semakin meningkat dari 3,567 mm menjadi 4,233 mm pada perlakuan yang ke-4 (empat).

\section{Pembahasan}

Nilai kadar aspal optimum (KAO) dengan filler abu batu adalah sebesar 6,5\%, dengan abu vulkanik sebesar $6,85 \%$. Selanjutanya pengujian campuran diuji dengan menggunakan variasi abu batu dan abu vulkanik sebagai bahan pengganti filler. Pengujian dilakukan dengan 7 perlakukan yang telah ditetapkan $\mathrm{di}$ atas. Pembahasan berikutnya adalah melihat perbandingan hasil parameter yang diperoleh jika bahan acuan adalah campuran filler dengan abu batu, dan hasilnya seperti pada Tabel 8 di bawah ini.

Tabel 8. Perbandingan Nilai Parameter Marshall Berdasarkan Filler

\begin{tabular}{|c|c|c|c|c|c|c|c|}
\hline No & Parameter Marshall & $\begin{array}{c}\text { Standard } \\
\text { SNI }\end{array}$ & $\begin{array}{c}\text { Abu } \\
\text { Batu }\end{array}$ & $\begin{array}{c}\text { Abu } \\
\text { Vulkanik }\end{array}$ & $\begin{array}{c}\text { Selisih } \\
(\Delta)\end{array}$ & $\begin{array}{c}\text { Abu Batu }+ \\
\text { Vulkanik }\end{array}$ & $\begin{array}{c}\text { Selisih } \\
(\Delta)\end{array}$ \\
\hline$[\mathbf{1}]$ & {$[\mathbf{2}]$} & {$[\mathbf{3}]$} & {$[\mathbf{4}]$} & {$[\mathbf{5}]$} & {$[\mathbf{6}]$} & {$[\mathbf{7 ]}$} & {$[\mathbf{8}]$} \\
\hline 1 & $\begin{array}{c}\text { Bulk density } \\
\left(\mathrm{gr} / \mathrm{cm}^{3}\right)\end{array}$ & & 2,43 & 2,4 & $-0,03$ & 2,41 & $-0,02$ \\
\hline 2 & Air void (\%) & $3-5$ & 4,9 & 4,8 & $-0,1$ & 4,78 &,- 012 \\
\hline 3 & VMA (\%) & $>15$ & 18,9 & 15,2 & $-3,7$ & 18,6 & $-0,3$ \\
\hline 4 & VFA (\%) & $>65$ & 67 & 68 & 1 & 74,5 & 7,5 \\
\hline 5 & Stability (kg) & $>550$ & 1020 & 1120 & 100 & 1000 & -20 \\
\hline 6 & Flow (mm) & $2-4$ & 3,32 & 3,72 & 0,4 & 3,2 & $-0,12$ \\
\hline 7 & Quetiont kN/mm & $2-3,5$ & 3 & 3,0 & 0 & 3,06 & 0,06 \\
\hline
\end{tabular}

Semakin banyak pertambahan pasir sinabung digunakan dalam campuran aspal beton maka stabilitas semakin menurun bahkan tidak memenuhi syarat yang diijinkan. Hal ini diakibatkan karena pasir sinabung banyak mengandung lumpur dan memiliki pori yang tinggi. Apabila ingin menggunakan pasir sinabung sebagai bahan konstruksi maka terlebih dahulu pasir tersebut dibiarkan beberapa waktu (penuan) agar kadar lumpur dan kadar belerang yang dikandung dapat berkurang.

Tabel 8 di atas menunjukkan bahwa parameter Marshall memenuhi standar SNI Jika material dengan filler abu batu sebagai acuan yang biasa digunakan, maka opsi penggunaan abu 
vulkanik dan opsi kombinasi (abu batu + vulkanik) tidak ada perbedaan yang signifikan. Maka dapat dikatakan bahwa opsi abu vulkanik murni dan kombinasi abu batu + vulkanik $(50: 50)$ sangat layak digunakan sebagai bahan campuran aspal beton ke depan.

Selanjutnya, Pemanfaatan pasir vulkanik sebagai material agregat halus (fine agregat) juga sangat dimungkinkan diaplikasikan sebagai material campuran aspal beton. Hal ini ditunjukkan dari hasil pengujian di laboratorium bahwa pasir vulkanik gunung Sinabung semburan 2 hari dengan perendaman 7 hari dikombinasikan dengan pasir biasa memiliki nilai Marshall yang memenuhi syarat SNI pada kombinasi 28\% pasir vulkanik dan $78 \%$ pasir biasa.

\section{Kesimpulan dan Saran}

Dari hasil pengujian dan analisa data yang dilakukan dapat diambil kesimpulan sebagai berikut:

- Abu vulkanik dapat dimanfaatkan sebagai filler dalam campuran aspal beton (hot mix). Jika abu vulkanik dan abu batu digabungkan maka kombinasi yang baik adalah $50 \%$ abu batu dan $50 \%$ abu vulkanik, dengan hasil nilai bulk density $2,416 \mathrm{~kg} / \mathrm{cm}^{3}$, air void $4,724 \%$, rongga dalam agregat (VMA) 18,667\%, rongga terisi aspal (VFA) 74,706\%, stabilitas 1000,992 kg, kekakuan 3,132 kN/mm, flow 3,133 mm.

- Pasir Sinabung dengan perendaman selama tujuh hari dapat digunakan sebagai bahan Fine Agregat dengan kombinasi 28\% pasir vulkanik dan 72\% pasir biasa.

Beberapa saran yang dapat diberikan berdasarkan penelitian ini antara lain:

- Abu Sinabung layak digunakan sebagai bahan campuran aspal beton.

- Pasir Sinabung juga dapat digunakan sebagai bahan konstruksi terutama pada campuran aspal beton apabila direndam.

- Penelitian lanjutan pemanfaatan pasir vulkanik dengan produksi yang lebih lama.

\section{Daftar Pustaka}

Departemen Pekerjaan Umum. (1990). Metode Pengujian Berat Jenis dan Penyerapan Air Agregat Kasar SNI. 03 - 1969 - 1990. Jakarta: Yayasan Badan Penerbit Pekerjaan Umum.

Departemen Pekerjaan Umum. (1990). Metode Pengujian Keausan Agregat dengan Mesin Abrasi Los Angeles SNI. 03 - 2417 - 1991. Jakarta: Yayasan Badan Penerbit Pekerjaan Umum.

Departemen Pekerjaan Umum. (1990). Metode Pengujian Tentang Analisis Saringan Agregat Halus dan Kasar SNI.03 -1968-1990. Jakarta: Yayasan Badan Penerbit Pekerjaan Umum.

Departemen Pekerjaan Umum. (2003). Metode Pengujian Campuran Beraspal Panas dengan Alat Marshall RSNI M 01-2003.

Harizon, N. Analysis Campuran Asphalt Concrete (AC) dan Bahan Pengisi dengan Metoda Marshall.

Sukirman, S. (1992). Perkerasan Lentur Jalan Raya. Bandung: Penerbit NOVA.

Sukirman, S. (2000). Material Perkerasan Jalan. Bandung: Institut Teknologi Nasional.

Sitohang, O. (2018). Bukho Stone Feasibility (Nias) As A Layer Subbase Course on The Pavement. International Journal of Scientific Research in Science, Engineering, 4(1), 579-581 